\title{
Exploration of Wadi Zerka Ma'in rotational fault and its drainage pattern, Eastern of Dead Sea, by means of remote sensing, GIS and 3D geological modeling
}

Odeh, Taleb, Gloaguen, Richard, Schirmer, Mario, Geyer, Stefan, Rödiger, Tino, et al.

Taleb Odeh, Richard Gloaguen, Mario Schirmer, Stefan Geyer, Tino Rödiger, Christian Siebert, "Exploration of Wadi Zerka Ma'in rotational fault and its drainage pattern, Eastern of Dead Sea, by means of remote sensing, GIS and 3D geological modeling," Proc. SPIE 7478, Remote Sensing for Environmental Monitoring, GIS Applications, and Geology IX, 74780K (7 October 2009); doi: 10.1117/12.829922 


\title{
Exploration of Wadi Zerka Ma'in rotational fault and its drainage pattern, Eastern of Dead Sea, by means of remote sensing, GIS and 3D geological modeling
}

\author{
Taleb Odeh $^{* 12}$, Richard Gloaguen ${ }^{2}$, Mario Schirmer, Stefan Geyer,' \\ Tino Rödiger', Christian Siebert ${ }^{\prime}$ \\ ${ }^{1}$ Department of Hydrogeology, Helmholtz Centre for Environmental Research - UFZ, \\ Halle, Germany; \\ 2Remote Sensing Group, Institute for Geology, TU-Bergakademie, Freiberg, Germany; \\ ${ }^{3}$ Eawag, Swiss Federal Institute of Aquatic Science and Technology, Department of \\ Water Resources and Drinking Water, Dübendorf, Switzerland
}

\begin{abstract}
The Wadi Zerka Ma'in catchment area is located in the North East of the Dead Sea. It contains a confined river of about $23 \mathrm{~km}$ length. The region is characterized by a recent sharp base level drop and a strong orographic control on climatic parameters such as temperature and precipitation. It is controlled by three regional structural systems as follow: 1) the anticline - syncline system (late Cretaceous - end of Miocene) which is a part of Syrian fold arc system; 2) NW - SE faults system which were generated simultaneously and parallel to the Red Sea spreading; 3) NWW - SSE faults system which are perpendicular to the Dead Sea and younger than the Red Sea fault system; 4) NNW - SSE faults system (middle Miocene - until now) which were generated simultaneously and parallel to the active Dead Sea transform fault. The structural setting of the study area was evaluated by means of a three-dimensional (3D) geological model, a digital elevation model (DEM) with resolutions 15 meters and stream profile analysis. DEM generation was performed using ASTER data. We found that the Wadi is located at the junction of two main fault systems. The major feature is a trans-tensional fault displacement which changes from 0 to $200 \mathrm{~m}$. We showed that the catchment area is a result of a rotational fault while the river changes its flow direction according to the different fault system directions. The lower portion of the basin is affected by the major base level drops and display contributing rivers in exceptional non-equilibrium. Thus this catchment allows observing the rapid adaptation of the drainage system to both climatic and tectonic forcing.
\end{abstract}

Keywords: Keywords: ASTER Image, DEM, 3D geological, Trans-tensional fault zone.

\section{INTRODUCTION}

The Wadi Zerka Maien catchment area is located in the north west of the Dead Sea and has an area of about $272 \mathrm{~km}^{2}$. It has a dendritic drainage system which runs directionally from north east to the west and discharges directly into the Dead Sea (Fig.1). Its cropping rocks are mostly sedimentary and belong to Cenozoic, Mesozoic and Paleozoic Eras. The lithological units of the upper part consist mainly of nonclastic sedimentary rocks. The lower part consists of clastic sediments. However, basalt, extrusive igneous rock, covers partly the lower part of the catchment area.Faults and folds have different directions, distributions and geological ages (Fig.2).

* taleb.odeh@ufz.de; phone (0)49-0345 558 5216; http://www.rsg.tu-freiberg.de; http://www.ufz.de/index.php?de=13319

Remote Sensing for Environmental Monitoring, GIS Applications, and Geology IX, edited by Ulrich Michel, Daniel L. Civco, Proc. of SPIE Vol. 7478, 74780K · @ 2009 SPIE · CCC code: 0277-786X/09/\$18 · doi: 10.1117/12.829922 
The aim of this research is to evaluate how structures influenced the structural setting and drainage networks of the catchment area through remote sensing techniques that provide a useful method for

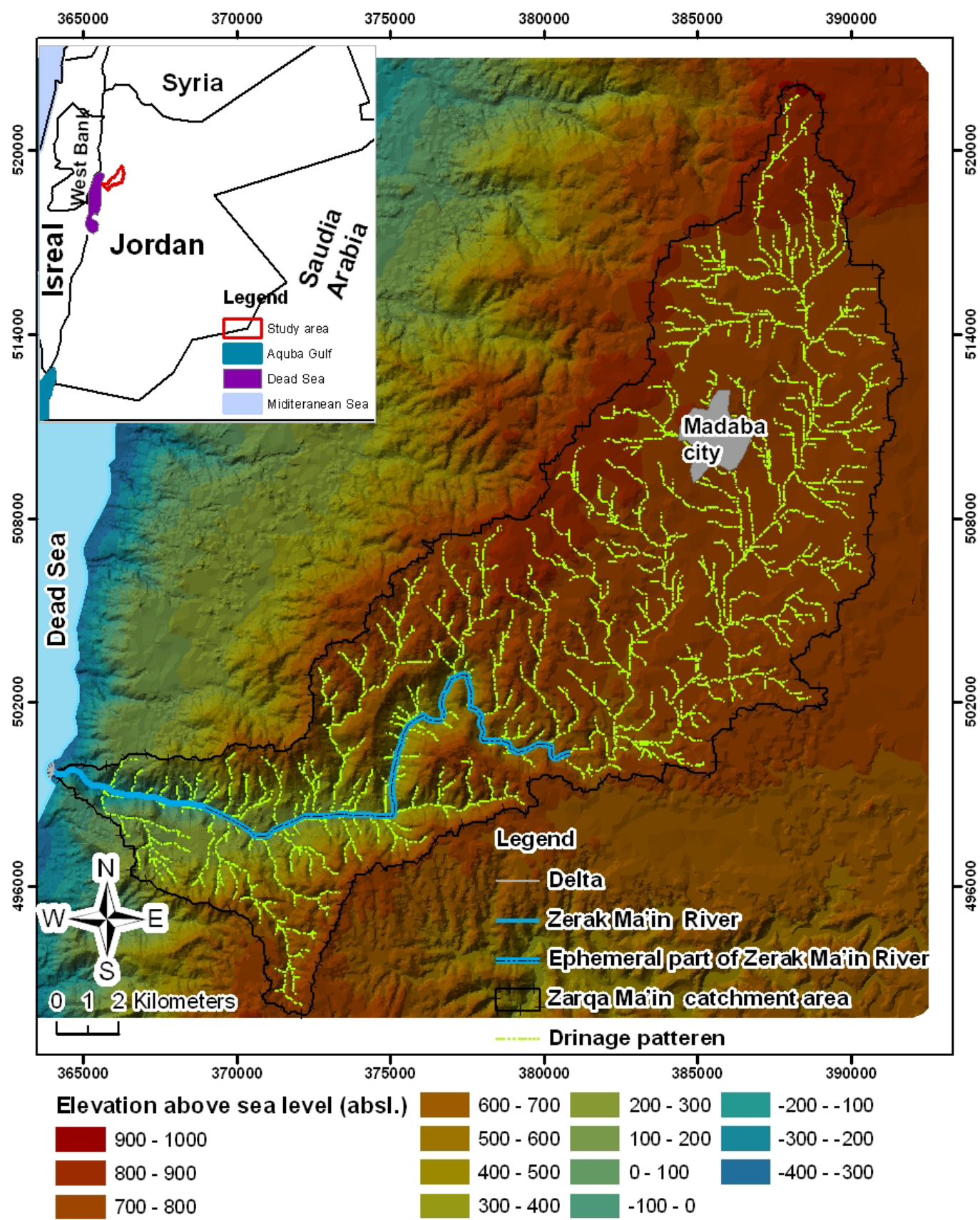

Fig.1: Location of Wadi Zerka Ma'in River catchment. The catchment area has a dendritic drainage pattern. Zerka Ma'in River is confined a River valley and partly ephemeral. 


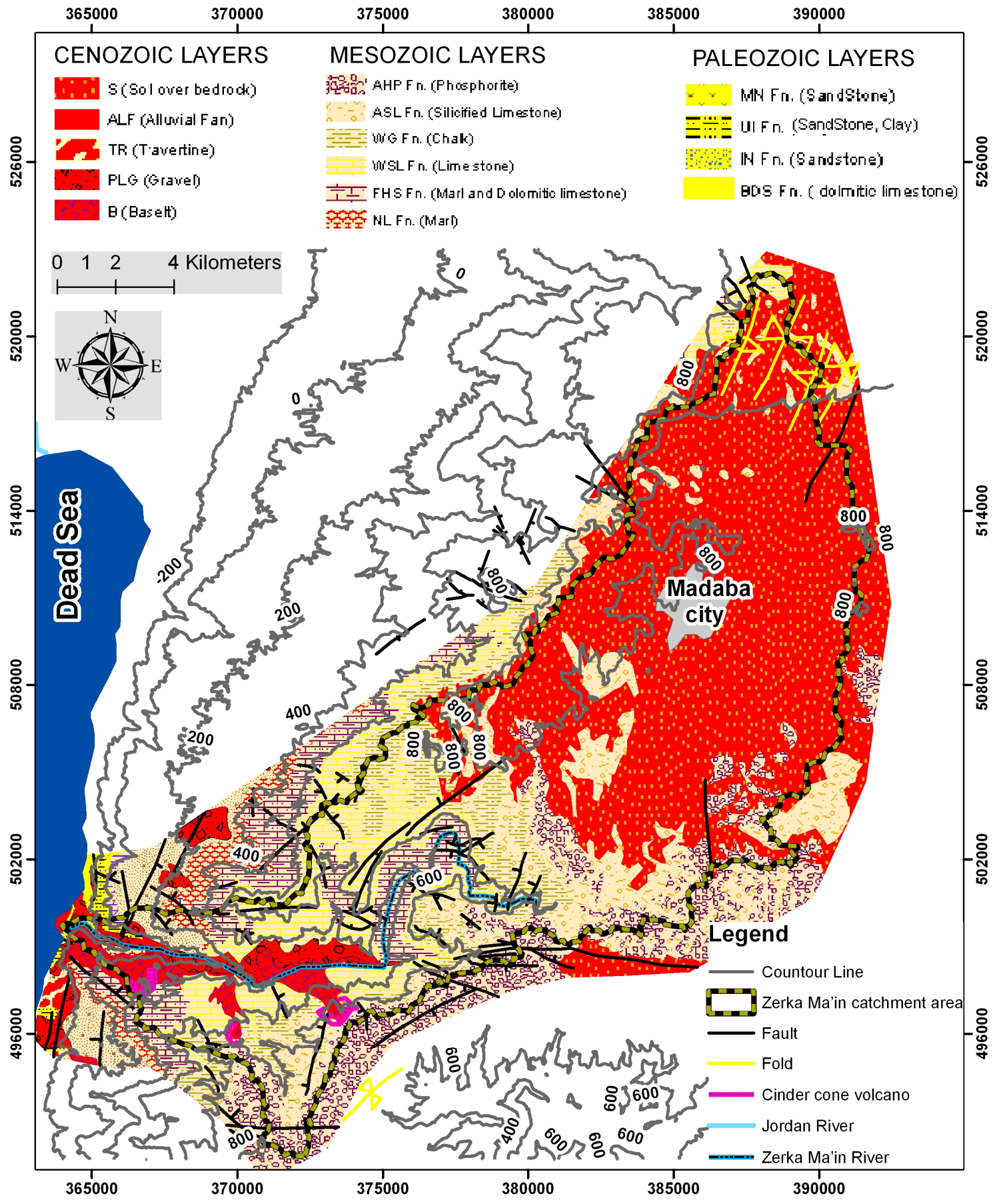

Fig. 2: The geological map of the study area (digitized from Natural Resources Authority maps sheet number 3153-I, 3153-II and 3153-III). Rocks of three Ears crop out in the study area: Cenozoic, Mesozoic and Paleozoic. 
a better description and interpretation of the geometry of the structures [1].

\section{GEOLOGY}

The Arabian-Nubian Shield, composed of Pre-Cambrian crystalline, performed in up and down movements during epirogenic activities since Pre-Cambrian time. The epirogenic activities resulted in marine transgressions and regressions of Tethys Ocean. The geological layers of the case study were deposited by the North West transgressions of the Tethus ocean and the erosion of the uplifting of the Arabian-Nubian Shield, from the south during the regression [2] (Tab.1).

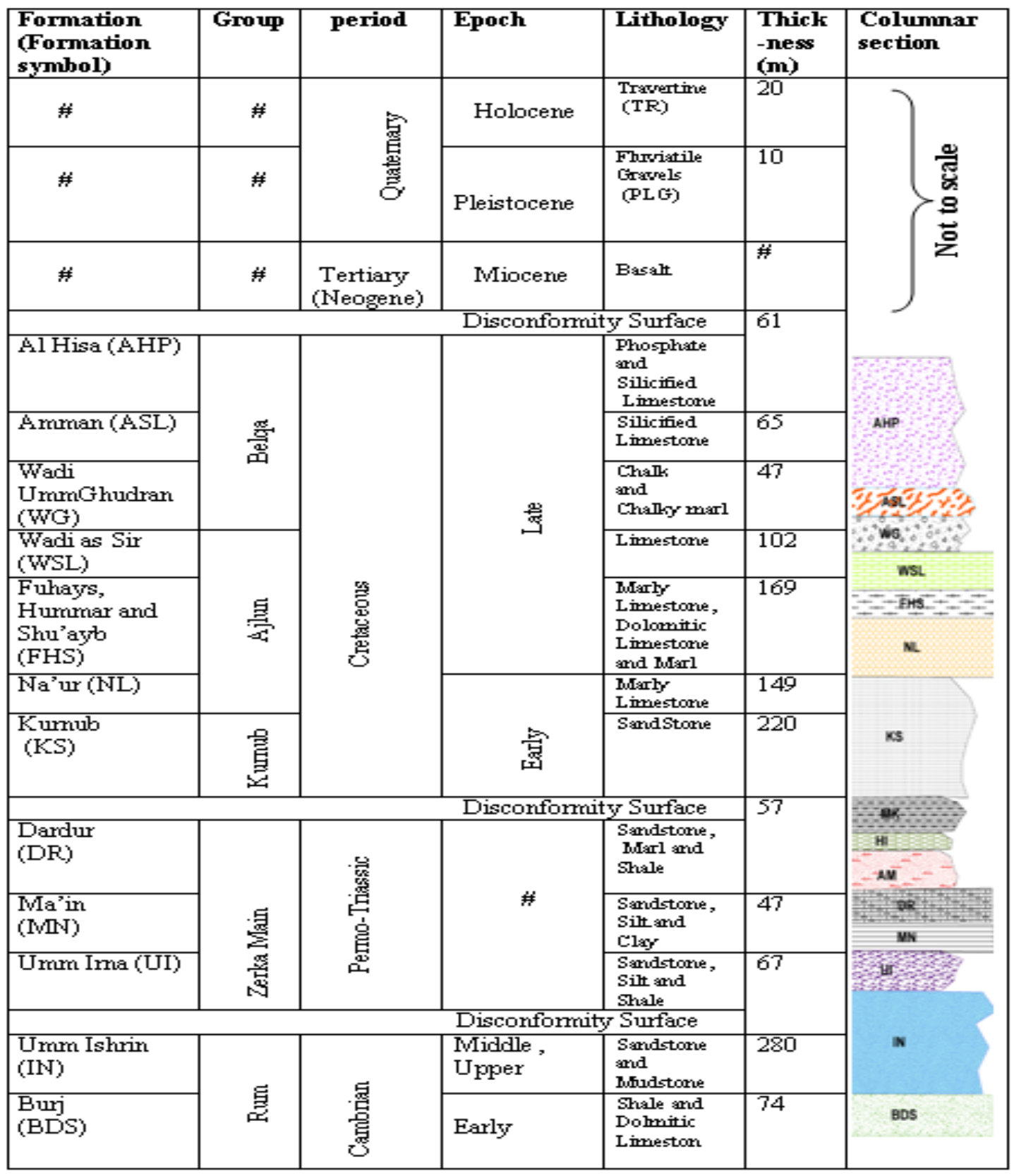

Tab.1: Geological layers of the study area. 
The quaternary rocks are mainly basaltic rocks from three plunges and have ages range from 0.6 to $6 \mathrm{Ma}$ BP [3]. The study area is located on the eastern side of the Dead Sea transform fault that represents part of the boundary between the African and Arabian plates with a rate of motion of about $6 \mathrm{~mm} /$ year. It connects the divergent plate boundary along the Red Sea with the zone of plate convergence along the alpine orogenic belt in Turkey [4].

There are three major fault systems in Jordan. The faults in the study area belong to those systems,: 1) NWSE faults system (parallel to the Red Sea): the oldest faults system which had been created simultaneously with the Red Sea spreading basin and has an age between mid-Oligocene to early mid-Miocene [5]; 2) NNW-SSE faults system(parallel to the Dead Sea): they were created simultaneously with the conservative movement along the Dead Sea transform faults, they are younger than previous faults system; 3) NWWSEE faults system (perpendicular to the Dead Sea): they are the youngest faults system in the area [6]. The anticline-syncline systems in the upper part of the catchment area belong to Syrian arc folds. They are a bundle of NNE-SSW to ENE-SSW trending folds which were created between late Cretaceous and the end of Miocene by mild compressional deformation [7].

\section{METHODOLOGY}

Remote sensing (RS) provides a synoptic view of the terrestrial landscape and is used for surveying, monitoring, and change detection analysis of natural resources. Geographic information system (GIS) are useful for the analyses of spatial and temporal parameters detected by remote sensing techniques [8].

An integrated approach of remote sensing and GIS was used to evaluate the structural setting and drainage network of the study area (Fig.4). ASTER Image 2005 was used to generate a $15 \mathrm{~m}$ (digital elevation model) DEM through Geomatica V10.3 software (Fig. 5).

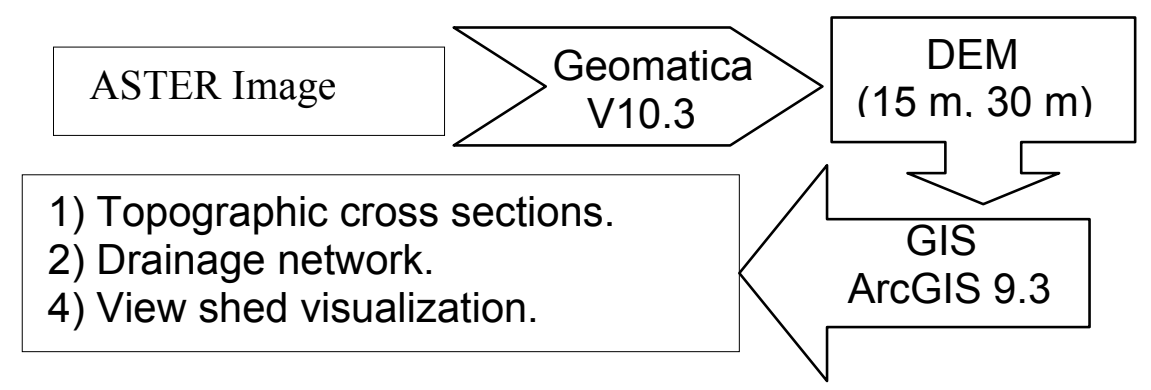

Fig. 4: Simplified workflow model.

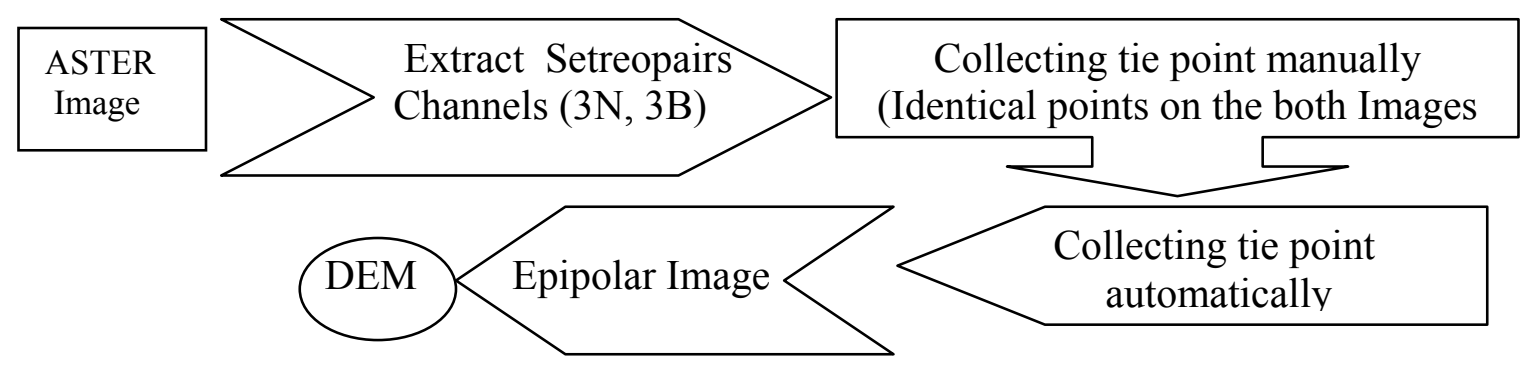

Fig. 5: Simplified workflow for DEM

ArcGIS 9.3 was used to extract the drainage network, water divides and to perform geo-referenced maps, digitizing, overlaying layers, view shed visualization and topographic cross sections (Fig. 6). The topographic cross sections were converted to geological cross sections which built a structural model through the GMS software. The thicknesses of the layers in the structural model were calibrated by actual 


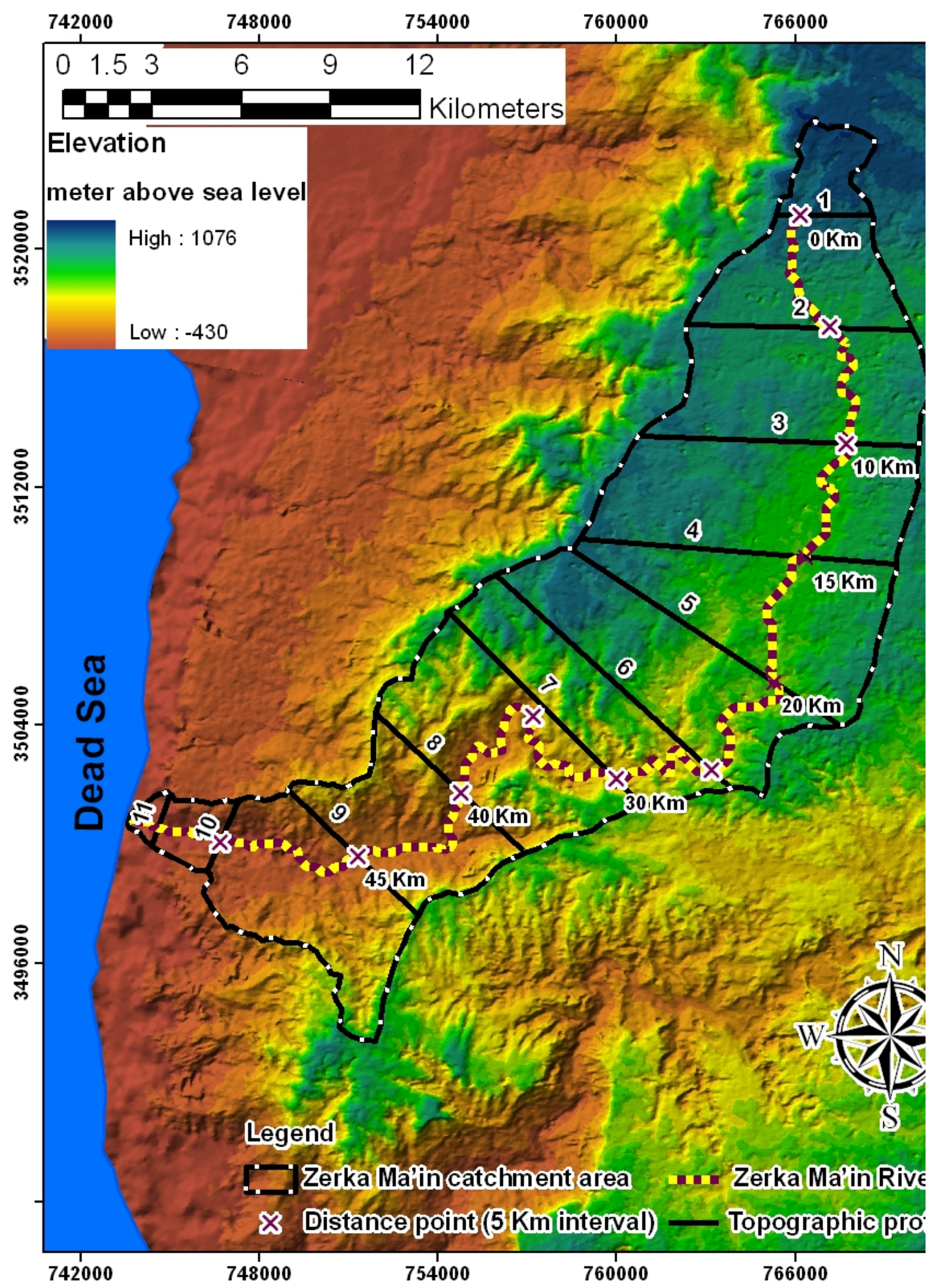

Fig. 6: DEM for the study area and the locations of the topographic profiles. 
boreholes. After that contractive interpolation for these cross sections was carried out to build a three dimensional (3D) stratigraphical model (Fig. 7).

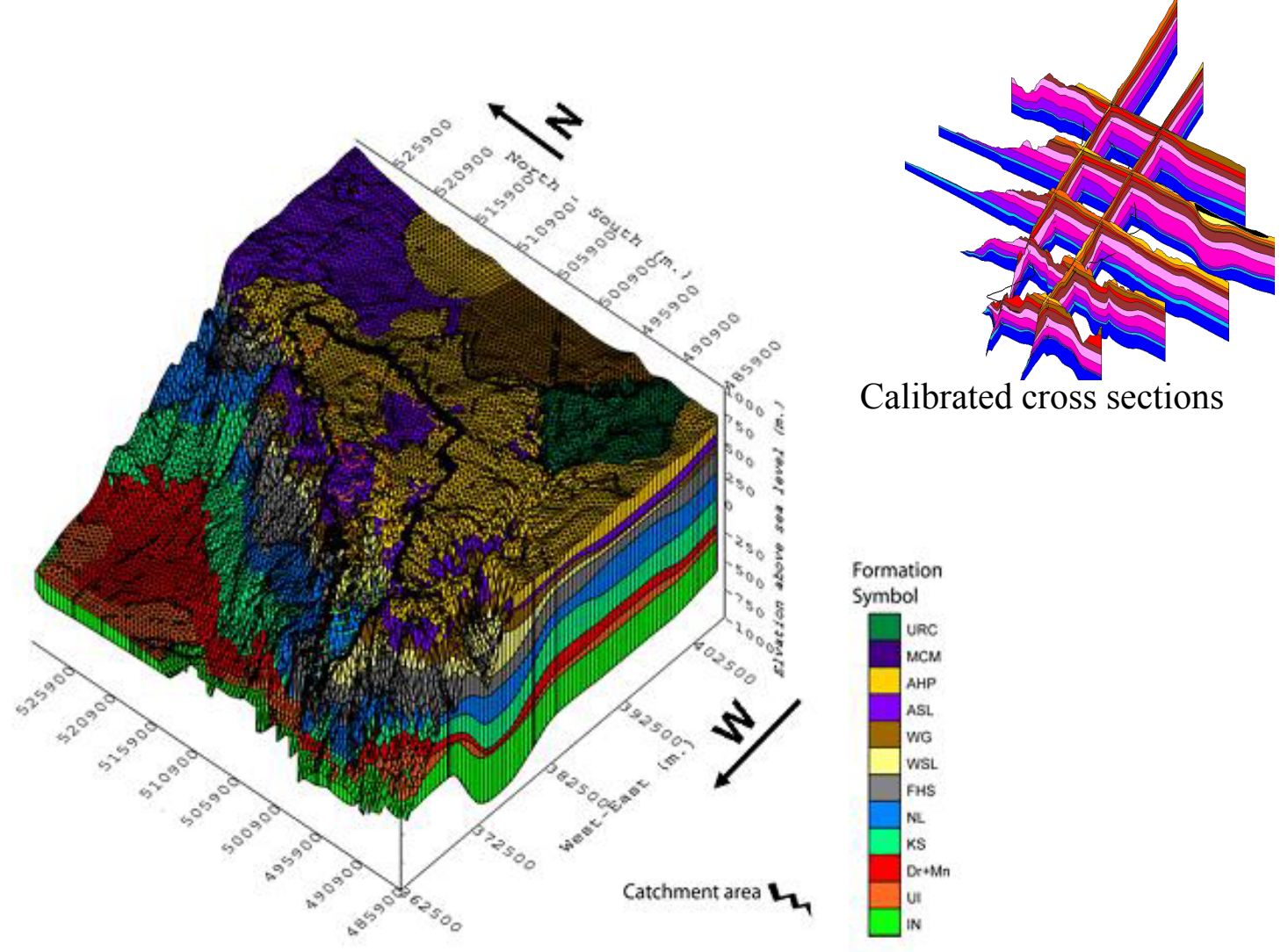

Fig. 7: 3D stratigraphical model of the study

\section{DISCUSSION AND CONCLUSION}

The drainage network of the case study area has exactly the same direction as the fault system in the study area as follow:

1) NW - SE drainage network that is parallel to the oldest fault system (Red Sea faults system); 2) NWW SEE drainage network that is parallel to perpendicular faults to the Dead Sea and youngest than the previous drainage network; 3) NNW - SSE drainage network is the youngest drainage network in the study area and parallel to the faults that are parallel to the Dead sea transform fault (Fig.8).

The topographic profile of Zerka Ma'in River and crosser lines (Fig.9) shows tow topographical dropping as follow:

1) $200 \mathrm{~m}$ elevation drop at the distance of $34 \mathrm{~km}$, in the middle of the catchment area (Fig. 10);2) $250 \mathrm{~m}$ elevation drop at the distance of $45 \mathrm{~km}$ at the lower portion of the catchment area. The first topographical drop is a result of trans-tensional fault zone (Fig.10). The second topographical drop is a result of river incision of sandstone units. This river incision was developed rapidly as a result of the fast declining of the Dead Sea level that reaches up to $1 \mathrm{~m}$ per year [9]. 


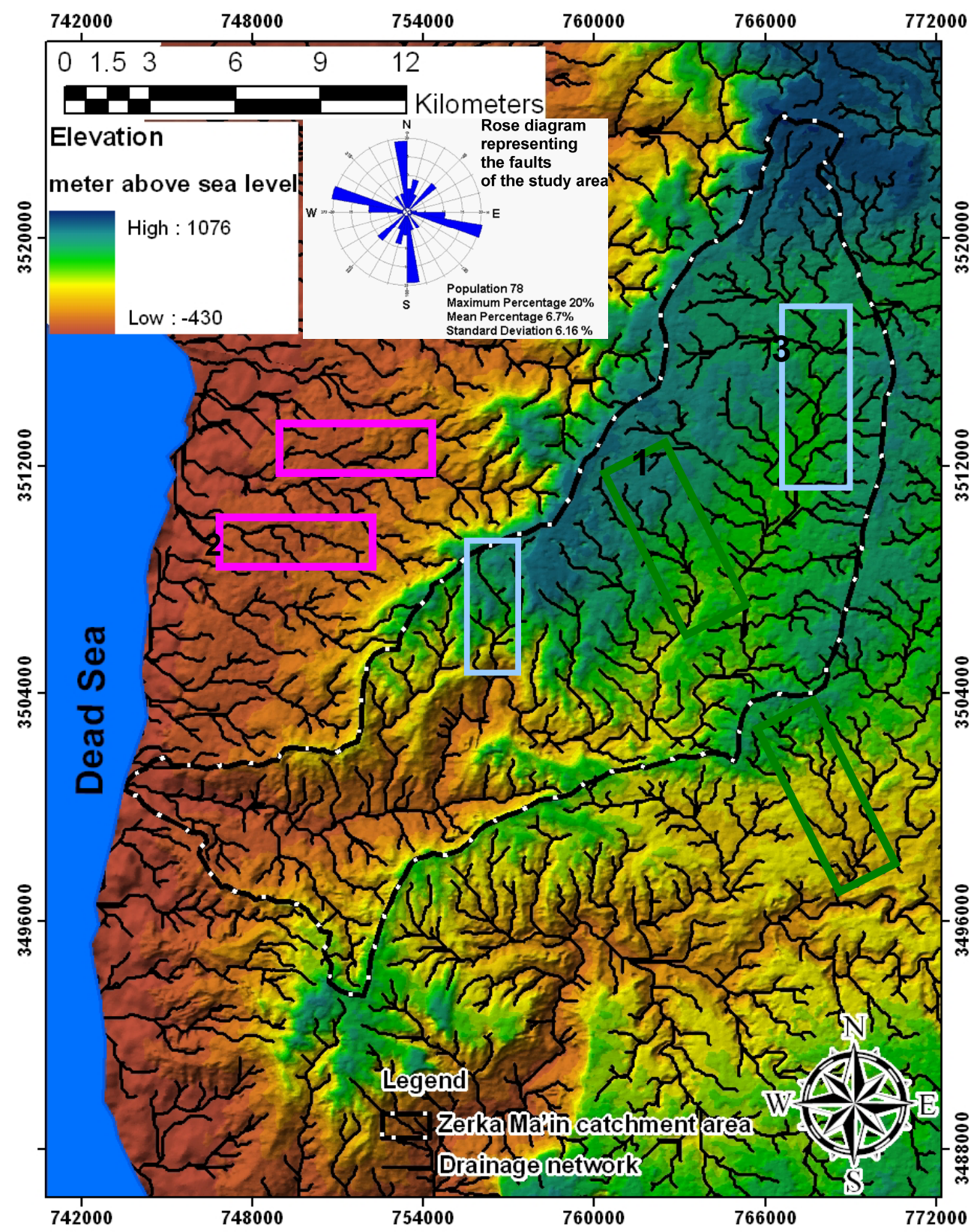

Drainage networks directions is similar to the faults directions (rose diagram) as follow:

1) Parallel to the Red Sea faults.

2) Perpendicular to the faults on the Dead Sea.

3) Parallel to Dead Sea transform fault.

Fig. 8: Drainage network directions in the study area. 

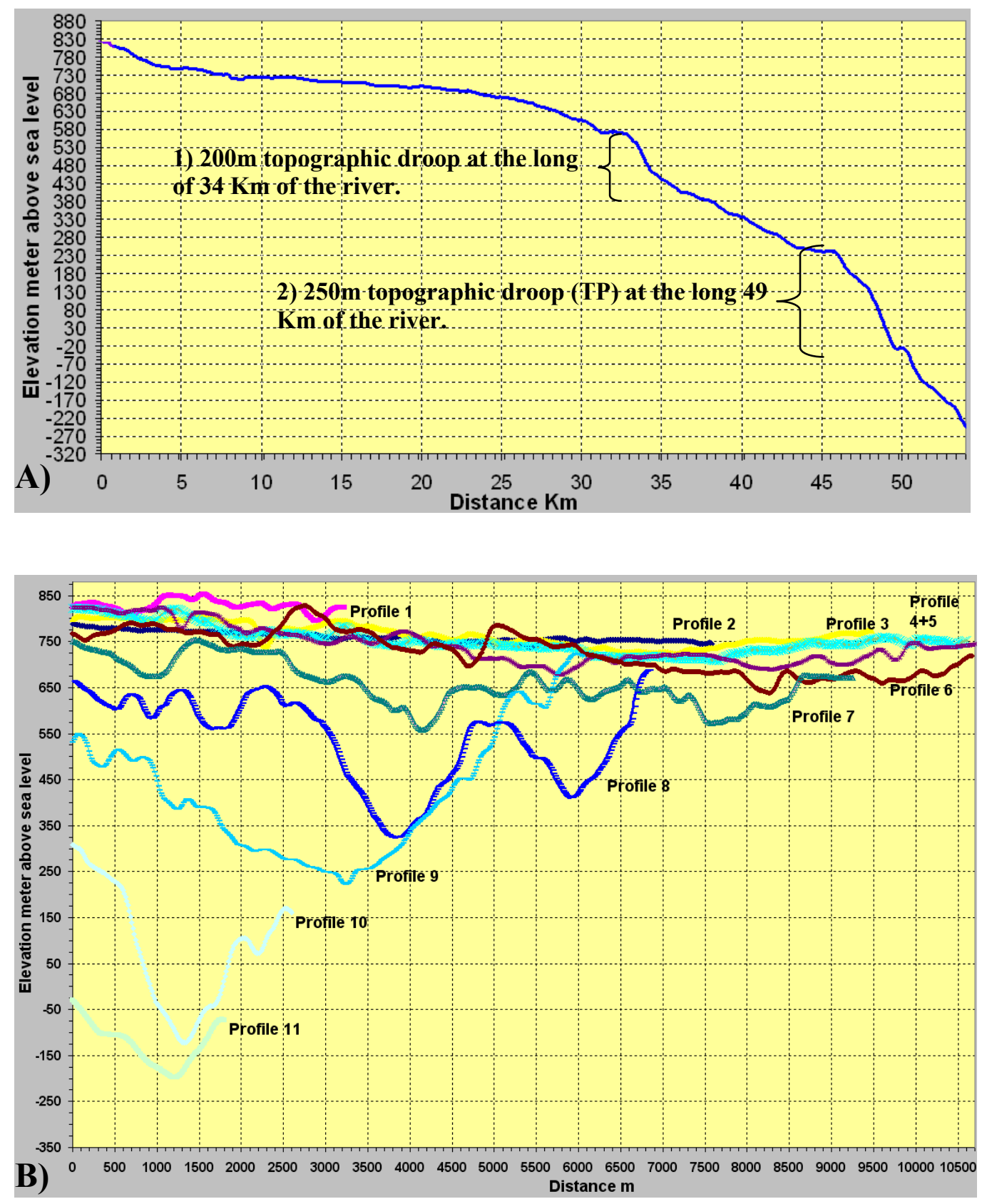

Fig. 9: A) Topographic profile for Zerka Main River.

B) Topographic profiles cross Zerka Ma'in River.

The catchment area of wadi Zerka Maien represents a rotational fault, with displacement from 0 to $200 \mathrm{~m}$ that was developed by the anticline-syncline system (Turonian - end Oligocene) at the top of the catchment area. The component of the three fault systems are: NNW - SSE that is parallel to the Dead Sea (youngest fault system), NWW - SEE perpendicular to the Dead Sea and NW-SE faults parallel to the Red Sea (the oldest fault system) (Fig. 11). 


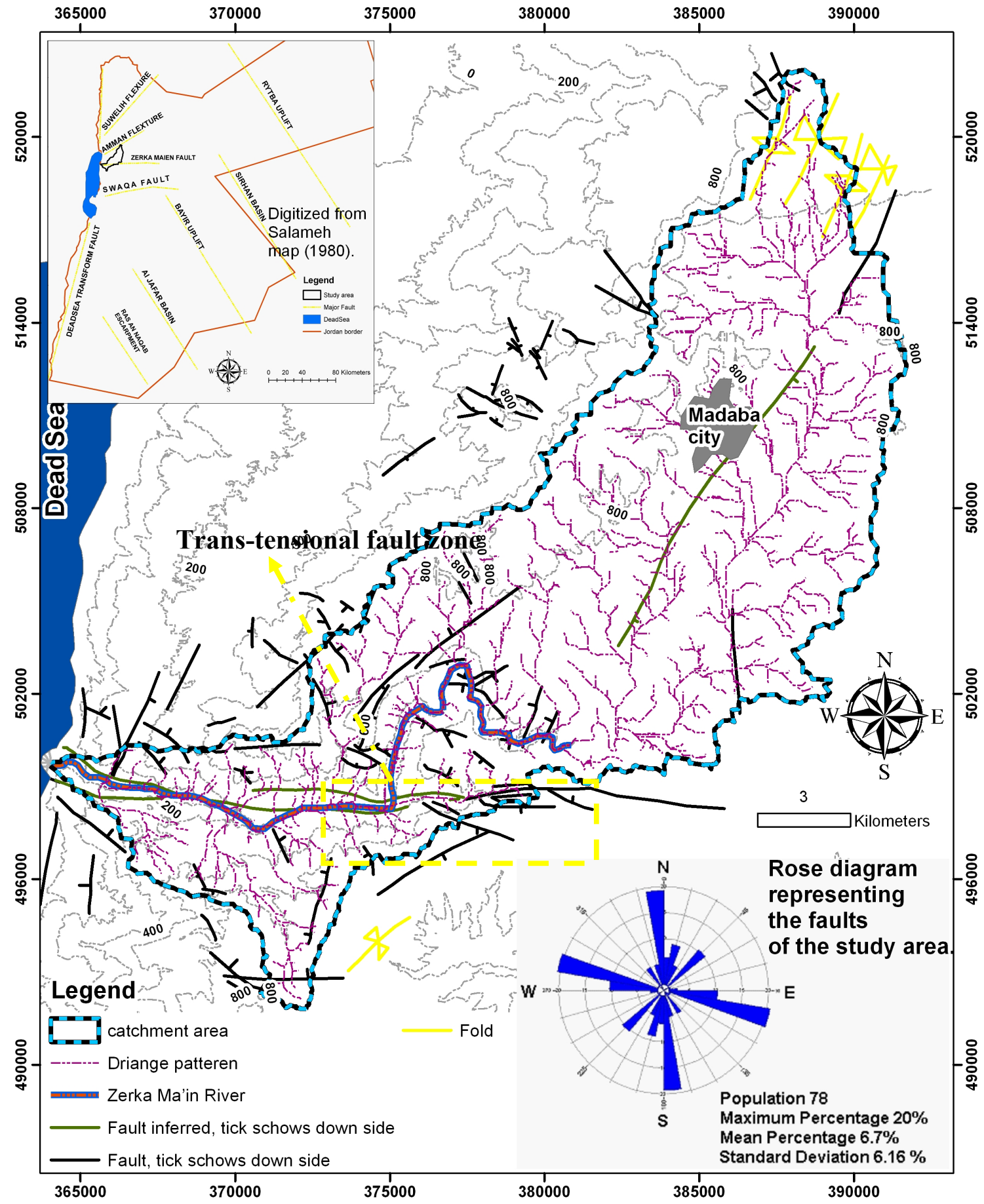

Fig 10: Location of the Trans-tensional fault zone in the study area. 


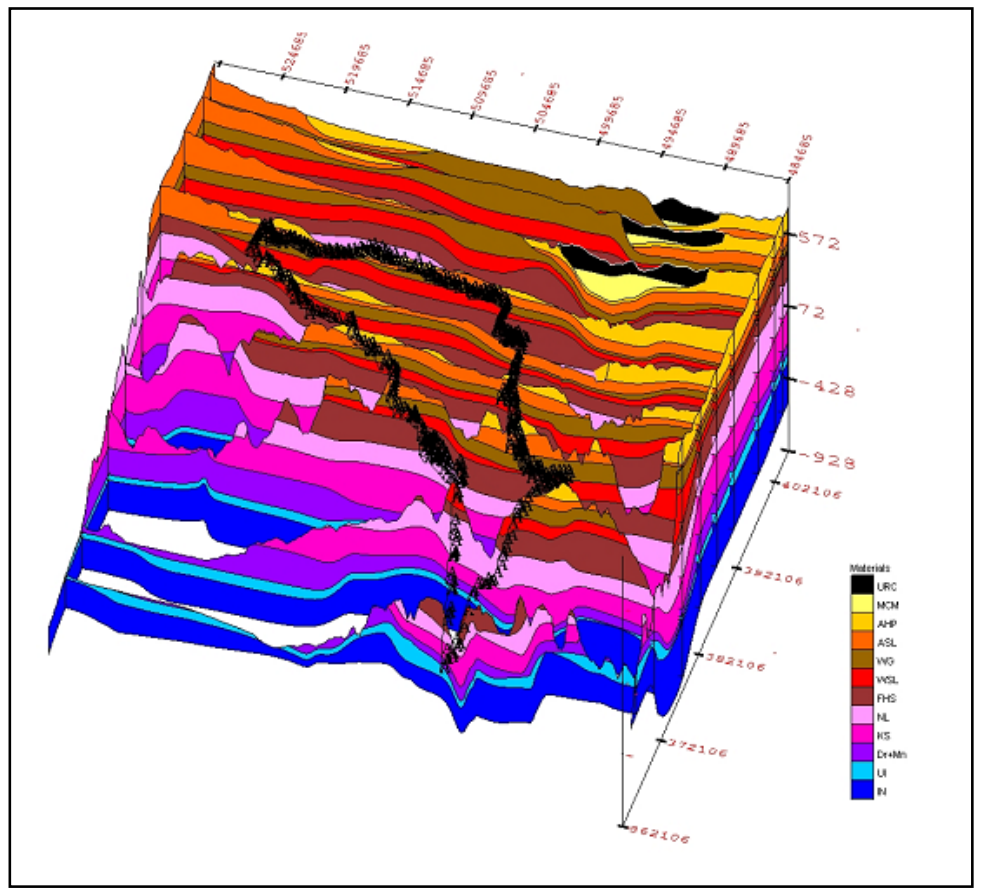

Fig 11: Location of the Trans-tensional fault zone in the study area.

\section{REFERENCES}

[1] S. Saintot et al. "Mechanical significance of structural patterns identified by remote sensing studies: a multiscale analysis of tectonic structures in Crimea," Tectonophysics 313: p. 187-218 (1999).

[2] F. Bender "Geology of Jordan, Contribution of the Regional Geology of the Earth". Borntraeger. p.196. (1974).

[3] G. Steinitz, et al., "The Miocene-Pleistocene History of the Dead Sea Segment of the Rift in Light of K-Ar Ages of Basalts," J. Earth Sci. 40:p. 199-208. (1992).

[5] Y. Eyal., "Stress field fluctuations along the Dead Sea Rift since the middle Miocene," Tectonics 15: p. 157-170. (1996).

[4] H.-J. Bayer, et al., "Sedimentary and structural evolution of the northwest Arabian Red Sea margin," Tectonphysics, v. 153, p. 137-151. (1988).

[6] E. Salameh "The Suwelih Structure,". , Polaon. p10. (1980).

[7] Z. Garfunkl, et al., "The structure of the Dead Sea Basin," Tectonphysics v. 266, p. 155-176. (1996).

[8] A. Saintot et al., " Mechanical significance of structural patterns identified by remote sensing studies: a multiscale analysis of tectonic structures in Crimea," Tectonophysics 313: p. 187-218. (1999).

[9] Getman, et al., "The Dead Sea hydrography from 1992 to 2000, Journal of Marine System" 35: p. 169181. (2002). 